\title{
Developing Student' Speaking Ability Through English Conversation Practice-Cudu Application
}

\author{
Imam Sudarmaji ${ }^{1}$ \\ \{isudarmaji@unis.ac.id $\left.{ }^{1}\right\}$ \\ Universitas Islam Syekh-Yusuf, Tangerang, Indonesia
}

\begin{abstract}
The aim of this research was to analyze the impact of English Conversation Practice-Cudu application in developing students' speaking ability. The researchers applied descriptive qualitative method with the mutiple sources; observation, test, and interview as the instrument of this research. In conducting this research, the researchers applied purposive sampling to select the participants that would be focused as the sample. The samples were students in the X MIPA 1 grade of SMAS PARADIGMA in academic year 2018/2019. There were thirty three students in the class, but the researchers only took six students as the sample, and the selecting of the sample based on the high, middle, and low scores in the pre-test. The results show that English Conversation Practice-Cudu application can improve students' speaking English ability and encourage students' motivation to practice speaking English and make them do learning English process well, and they get increasing in their speaking English ability after implementing this application. Besides, the students can use their mobile phone effectively and they also can enjoy in practicing English speaking by English Conversation Practice-Cudu application. This application is suitable to be implemented in developing students' speaking English ability and it can be used as a media for teaching English speaking.
\end{abstract}

Keywords: English conversation practice-Cudu application, practice English speaking, speaking ability

\section{Introduction}

Speaking is a productive language skill. Its mean that is a persons' skill to produce sounds and form a meaning when uttered that can be understood by other people, so that they will be able to create good communication. Chaney (1998) state that "Speaking is the process of building and sharing meaning through the use of verbal and non-verbal symbol, in a variety of contexts" [1].

In this era, speaking English is very important and needed. Because many aspects have used English language for communication. English has been used in businees, technological, daily communication and other purposes. Speaking is an important tool for communication, think, and learn. But not all people master or able to speak English whereas it is as one of the language skills that becomes important topic in language teaching. Speaking is one of the four macro skills necessary for effective communication in any language, particularly when speakers are not using their mother tongue. This is supported by Zaremba (2006) "Of all the four macro English skills, speaking seems to be the most important skill required for communication" [2]. So, speaking skill is important to support communication in many aspects. As cited by Osborn et al. (2008) Effective communication by means of speaking usually creates a number of 
benefits for both speakers and business organizations. For example, effective speaking skills result in achievements during ceremonial speaking activities, job training activities, job interviews, and many other business purposes [2].

As far as we know, English is as a foreign language in Indonesia and international language in the world. So the young generations should be able to speak English by studying and practicing. Young generations of course have studied and practiced speaking English at out or inside of school. In fact, most of them only practice at school. At school not only focus in English lesson and not all English lesson will discuss about speaking, so they just have a little opportunity to practice speaking English. Futhermore, if the method and approach which are used for teaching is not effective. It will occur a problem that is the students will be longer to able to speak English.

Based on information obtained the English teacher at SMAS PARADIGMA, English speaking was not considered easy for students and not all students were able to speak English because they just had a little opportunity to practice at school. Many students who were lazy to practice and they got difficulties in speaking English. So this is the challenge for educators to encourage them so that they have motivation to practice. Educators should apply the fun and enjoy learning to encourage them so that they are not lazy to practice speaking English. One of ways to overcome this problem, the researchers thought to use English Conversation PracticeCudu application which is on mobile phone as one of medias in teaching.

English Conversation Practice-Cudu application is the educational application to practice English conversation effectively. It has many topics of conversation that will help students improve speaking skill and make the students as a native speaker and we can learn how to speak English like a native speaker through dialogue lessons. The application help us immediately improve our communication skill in English (in daily communication, travel, shopping, work, weather, and others), support for learning, research, job, travel, study abroad, and labor export [3]. technology brings flexibility and choice to education [4].

As far as we know, the current students can not be separated by mobile phone and they often waste their time with useless activity instead of study. To minimize their useless activities in using mobile phone, the researchers want to do research using English Conversation PracticeCudu application for students to practice speaking English. According to Marcinkiewicz [5] "It is believed that technology can improve teaching and learning and the quality and quantity of teaching and learning".

The researchers' objective do this research because they want to know wheather this application will give a positive influence for students or not. Hopefully, by applying English Conversation application can build their enthusiasm and motivation to practice speaking English, and achieve their speaking skill.

\section{Method}

This research used a qualitative research. "Qualitative research is an inquiry process of understanding a social or human problem, based on building a complex, holistic picture, formed with words, reporting detailed views of information and conducted in a natural setting" [6. It means that the data that were gathered by the researchers based on the facts in the field. The researchers applied mutiple sources; observation, test, and interview as the instrument of the research to find whether the use of English Conversation Practice-Cudu application can depelove students' speaking ability or not. 
The researchers used purposive sampling. Purposive sampling is intentional selection of informants based on their ability to elucidate a specific theme, concept, or phenomenon [7] It was applied so that the researchers could be more focused with the participants that were chosen. The samples were students in the X MIPA 1 grade of SMAS PARADIGMA in academic year 2018/2019. There were thirty three students in the class, but the researchers only took six students as the sample. The selecting of the sample based on the high, medium, and low scores in the pre-test, so the researchers took two students who got high scores, two students who got medium scores and two students who got low scores. We had conducted this research for nine days, the first day was pretest, the second day until the eighth day were treatments and the last day was post-test and interview. In analyzing the data, the result of observation, speaking test, and the result of interview from six students were described and analyzed to answer and prove the aims of this research.

\section{Finding and Discussion}

In doing this research, the researchers did observation, test, and interview to collect the data. Observation had been done before treatments, along treatments, and after treatments. Before threatment, the researchers conducted the pre-test to the students and after threatment, the researchers conducted the post-test to the students. In the last sesion, the researchers conducted interview to the students after post-test. After analyzing the data from observation, test, and interview, the researchers described the result of the students when using English Conversation Practice-Cudu application as a media in learning English speaking.

\subsection{Observation \\ 3.1.1 The first observation}

The first observation had been done on April $30^{\text {th }}, 2019$ from $13.00 \mathrm{pm}$ to $14.30 \mathrm{pm}$. The students greeted the researchers kindly and friendly. The class situation was quite orderly but it was also quite tumultuous. The first researchers greeted the students and checked the attendence of them in the class. There were 33 students in the class of X MIPA 1 grade of SMAS PARADIGMA. The location of the school on Jl. Ir Sutami Mauk-Tangerang. From 33 students who attended in the class, but we only focused on 6 students as our sample in this research. However, to sellect them as the sampe, we conducted them to do pre-test in the first meeting. The pre-test was introducing about themselves in the class. It run for 90 minutes. In doing pretest many students who were not still confident and fear to speak English, however we persuaded them to try to speak English, fortunately they did it even though the result was not like we had expected, but there were some students who did it passably. These results were as the first data to be compared with post-test after treatments by using English Conversation Practice-Cudu application as media to learn and practice speak English.

\subsubsection{The second observation}

The second observation had been done along treatments on 1, 2, 3 May 2019 from 14.00 pm to $15.00 \mathrm{pm}, 8$ and 9 May from 10.30 am to 11.30 am, and 10 until 13 May 2019 from 8.00 to $9.00 \mathrm{am}$. For 7 days, the researchers conducted treatments to the students and every meetings had run 60 minutes. On the first treatment, there were 33 students in the class. They looked happy to study with us. First, the researchers instructed them to download English Conversation Practice-Cudu application on play store. And the researchers introduced and demonstrated that 
application. They were enthusiasm in using that application to practice speaking English. Their spirits quite arisen to learn and practice speaking English after the researchers had introduced that application. In the application contains some chapters and every chapters contain some topics to practice speaking English. Every meeting they were conducted to learn one topic.

On the second treatment until the last treatment they had progress every meeting. They were more better than previous day and so on. Their progresses in speaking had occured when they known and used English Conversation Practice-Cudu application as the media to learn and practice English speaking even though their progresses were not perfect but these were quite well. Along studying and practicing speaking English by using English Conversation PracticeCudu application, they were enthusiasm, enjoy, and they looked cheerful and happy in the class. They were like playing game when they learn and practice speaking English by using that application. In the treatment, they practiced individually and also the researchers instructed some of them to come forward in the class to practice so that they were more confident to speak English. Every meeting, their confident to speak English were increased. They seemed relish doing this threatmet. And the situations in the class every meeting were orderly and they obediented what the researchers instructed.

\subsubsection{The Last observation}

The third observation had been done on $14^{\text {th }}$ May, 2019 from 13.00 to $14.30 \mathrm{pm}$. It had been done along post-test was doing. The situation along post-test had run orderly. All students attendend in the class, including the students who the researchers have sellected as the target samples in this research. The post-test that was done by students was introducing themselves as a new employee in a company. They did it by coming forward the class one by one. There were differences when they did pre-test and post-test, that is they did speaking test in post-test without persuading by the researchers, however they did it confidently. They were enjoy in doing posttest, and there were many increasing before and after treatments. When they were doing posttest, they more fluent than pre-test. The post-test run for 90 minutes.

The overall obsevation result were carried out during pre-test, treatments and post-test. There were differencess along the first observation, the second observation and the last observation both from the situation in the class, the condition of the students, or the increasing student in following the learning process. They were more enjoy, interest and enthusiastic after they were conducted to study by using English Conversation Practice-Cudu application as the media to learn and practice speaking English.

\subsection{Test}

\subsubsection{Pre-test}

Pre-test had been conducted on April 30 ${ }^{\text {th }}, 2019$ from 13.00 to $14.30 \mathrm{pm}$. It had been done to know the students' initial abilities toward speaking English. The time for administering the pre-test was 90 minutes. The pre-test was introducing themselves in the class. We had conducted the pre-test to 33 students to find the high score, medium score and low score based on their pre-test scores. After that we selected 2 students who got the high scores, 2 students who got medium scores and 2 students who got low scores, then we focuced to them as the samples. Finally the researcher obtained the pre-test results. The assessment was based on scoring rubric speaking assessment by Dra. Handayani Sumarno M.Ed. Below are the table of the pret-test result [8]. 
Table 1. Students' speaking scores before using CUDU Application

\begin{tabular}{ccc}
\hline No & Students & Pre-test Score \\
\hline 1 & PH & 69 \\
2 & HY & 69 \\
3 & AN & 56 \\
4 & EA & 50 \\
5 & AP & 31 \\
6 & AF & 25 \\
\hline
\end{tabular}

Based on the table above, there are 6 students from 33 students who had been selected by the researchers from the result of their pre-test scores. From 33 students, the higest pretest score is 69 and the lowest pre-test score is 25 . The researchers chose 2 students who got 69 scores in the high score category, 2 students who got 56 and 50 scores in the medium score category, and 2 students who got 31 and 25 in the low score category. Those chategories are based on the result of their pre-test scores. Howeover, based on the criteria of the higest, middle, and lowest English subject scores in SMAS Paradigma is 70-75 are the low scores, 76-80 are the middle scores, and 81-100 are the high scores. Based on the table above, all students are in the low scores based on critertia of English subject scores in SMAS Paradigma. So, this showed that the students' speaking English ability was still weak. Some problems that occured on their speaking English that they were not still confident to speak, and also they were not still weak to pronounce the words appropriately.

\subsubsection{Post-test}

Post-test had been conducted on May $14^{\text {th }}, 2019$ from 13.00 to $14.30 \mathrm{pm}$. It had been done to make sure the improvement of student learning outcomes, the researcher conducted the posttest in the nineth meeting. It has run 90 minutes. The post-test was introducing themselves as a employee in a company. The researchers gave the post-test with the same test indicator so that their ability in speaking English lesson could be clearly identified or not. We conducted all students to do post-test but we only focused on 6 students who got high, medium, and low scores based on their pre-test scores that had been selected by the researchers. Below are the result of post-test.

Table 1. Students' speaking scores after using CUDU Application

\begin{tabular}{ccc}
\hline No & Students & Post-test Score \\
\hline 1 & PH & 81 \\
2 & HY & 75 \\
3 & AN & 69 \\
4 & EA & 81 \\
5 & AP & 56 \\
6 & AF & 56 \\
\hline
\end{tabular}

Based on the table above, the result of their post-test scores showed higest than their pretest scores. The students who got low scores in pre-test had incresed scores in post-test. Besides that, the student with initial $E A$ who got medium category score in the pre-test, she got score that same with student with initial $P H$ who got score in the high category score in the pre-test. 
On the table above, all students had increased on their scores in the post-test. In addition, based on the criteria of the high, middle, and low English subject scores in SMAS Paradigma, student PH and student EA's scores are in the high scores, but others are in the low scores. Although more students got the low scores that based on English subject scores in SMAS Paradigma, they got an increase in scores of post-test after they had been conducted in threatments to practice speaking English by using English Conversation Practice-Cudu application.

It can be concluded that there was a significant increase in students' speaking English ability after learning and practicing speaking English by using English Conversation PracticeCudu application. It is supported by Marcinkiewicz (1994) in Samadi, Maghsoudi, and Azizmohammadi (2014) "It is believed that technology can improve teaching and learning and the quality of teaching and learning". Furthermore as cited by İlin et al. (2013), technology brings flexibility and choice to education (Crawford, 2002). It means that English Conversation Practice-Cudu application can give positive impact for students in developing their speaking English ability.

\subsection{Interview}

Interview had been conducted on May 14th, 2019 after post-test from 14.30 to $15.00 \mathrm{pm}$. It had been done to support the previous finding of this research and also to strengthen the result of this research. The researchers interviewed 2 students who got high scores, 2 students who got medium scores, and 2 students who got low scores regarding English Conversation PracticeCudu application as a media to learn and practice speaking English. The result of interviewed from student $\mathrm{PH}$ said that English Conversation Practice-Cudu application was quite helpful to practice speaking because by this application she has known the ways to pronunce English words appropriately. Besides, there were the sentence translation so she could know the meaning of the sentence, and this application was fun and she got a change in her speaking ability after using this application. After that, student $H Y$ also said that this application was helpul to study English speaking and she was fun in using this application and she got good progress in speaking English more. Then student $A N$ also gave positive response, he said that this application was quite helpful because by this application he could know the ways to read and pronunce English words appropriately and correctly and he was happy because he could read and speak English fluently, he was really fun in using this application and also this application gave him a change in his speaking ability and also he could know more than before using this application. Student EA also gave positive response about this English Conversation Practice-Cudu application, she said that this application was quite helpful to study speaking English, and also by using this application she could easily understand how to speak English correctly and this application was fun to use and also there was a change that previously she have not able to speak correctly but after using this application she could more able to speak English correctly. Then student AP said that this application was quite helpful to learn and speak English and he was happy and fun in using this application and he got many changes in his speaking English ability. Lastly student $A F$ also gave a positive response that this application was helpful him to practice speaking English, and he was fun in using this application and also he got a change in his speaking English ability after using English Conversation Practice-Cudu application

From the results of interview, it means that the students felt happy, fun, and enjoy in learning and practicing English speaking by using English Conversation Practice-Cudu application. Therefore they could do learning process well. Besides, they got change and increase in their speaking English ability after using this application as a learning media to learn 
and practice speaking English. So, English Conversation Practice-Cudu application really gives positive impacts for students.

\section{Conclusion}

Based on the finding and discussion above, it can be concluded that English Conversation Practice-Cudu application can give positive impact in developing students' grammar ability at class X MIPA 1 In addition English Conversation Practice-Cudu application can improve students' speaking English ability and also encourage their motivation to learn and practice speak English more. The teacher can apply this application as a media for teaching speaking English. Besides that the students can use their mobile phone effectively and they more enjoy when they practice English speaking by using English Conversation Practice-Cudu application. So, it can be said that English Conversation Practice-Cudu application is good media for develoving students' speaking English ability.

\section{References}

[1] Rahmawati, Agnes et al. Improving Students' Speaking Skill of Grade VII A at SMP Negeri 1 Kasihan Bantul Through The Use of Cue Cards in The 2016/2017 Academic Year. English Language Teaching Journal, 6, No 11/2017, 1 (2017)

[2] Boonkit, Kamonpan. Enhancing the development of sepakung skills for non-native speakers of English. Procedia-Social and Behavioral Sciemces, 1306 (2010)

[3] Anonymous. English Conversation Practice-Cudu. Retrieved from https://m.apkpure.com/ englishcomversationpracticecudu/com .Conversationenglish Accesed on $12^{\text {nd }}$ March 2019 at 13.00 pm (2019)

[4] İlin, G., Kutlu, Ö., \& Kutluay, A. An Action Research: Using Videos for Teaching Grammar in an ESP Class. Procedia - Social and Behavioral Sciences, 70, 272-281.https://doi.org/10.1016/j.sbspro.2013.01.065 (2013)

[5] Samadi, F., Maghsoudi, M., \& Azizmohammadi, F. The Impact of CALL Technology on Improving Iranian Female Highschool Students' Speaking Ability. Procedia - Social and Behavioral Sciences, 98(2011), 1666-1671. https://doi.org/10.1016/j.sbspro.2014.03.591 (2014)

[6] Creswell, J. W. Research design : Qualitative, quantitative, and mixed methods approaches. (Second Edition). Thousand Oaks : Sage Publication (2002)

[7] Robinson, Rabecca S. Encyclopedia of quality of life and well-being research.pp 5243-5245. Retrieved from link.springer.com/10.1007/978-94-007-0753-5_2337 (2014)

[8] Sumarno, Handayani. Pusat Penilaian Pendidikan. Jl. Gunung Sahari Raya No.4 : Eks Komp Siliwangi 1000 